\title{
Abstract
}

Adapting the Motet(s)? The case of Hé bergier in Oxford MS Douce 308

The present article seeks to further recent discussion of the diversity of the motet in the long thirteenth century by considering a specific, rather unusual example of motet-related materials in a songbook. It examines a two-stanza pastourelle in the songbook that forms part of Oxford, Bodleian Library MS Douce 308, and its relationship to a network of related materials in various thirteenth-century motet sources. In so doing, it proposes the ostensibly unlikely scenario that this monophonic song derives from two separate motets that may already have been linked through their shared tenor and possibly also performed together in some way. This article brings the important conclusions of Fred Büttner in regard to these materials to Anglophone scholarship, while nuancing his reasoning in light of more recent scholarly on thirteenth-century motets copied in songbooks. 


\section{Adapting the Motet(s)? The case of Hé bergier in Oxford MS Douce $308^{\star}$}

The history of the thirteenth-century motet is being gradually re-fashioned, not least because of the heterogeneity of the many musical pieces that are collected under this generic label in modern editions. Those things termed motets today are to some extent a hybridization of other genres and their transmission history-being largely collected retrospectively after significant use, adaptation, and further hybridizationmakes it difficult, perhaps impossible, to uncover with certainty the pathway by which any given medieval motet was generated. Earlier studies of motets focused on socalled 'motet books', which seem to represent a central, Parisian tradition of thirteenth-century liturgical polyphony. These books offer a picture of motets deriving from the trope-like Latin texting of sections of discant (note-against-note counterpoint) within organa (polyphony built on a plainchant tenor). These motet books present motets as a further ornament to specific festive liturgies in the sacred world of the church, with later French contrafact texts viewed as exploring allegorical parallels between sacred and secular spheres. ${ }^{1}$ More recent work has proposed two kinds of extension to this basic history. First, building on sporadic earlier work that had been seen at the time as iconoclastic or even quixotic, Catherine Bradley has shown that sometimes, even when a clausula and Latin-texted version exist, the vernacular motet in a given motet network can affect earlier versions retrospectively or may itself represent the original form of the piece. ${ }^{2}$ Second, work by Gaël SaintCricq has taken seriously the seemingly anomalous (but actually quite large) presence of motets in trouvère songbooks, emphasising the songlike aspects of certain motets' construction, including those in the 'central' tradition, and proposing a more complicated and diverse story of their origins. ${ }^{3}$

\footnotetext{
${ }^{*}$ My work on D308 has been generously funded by the Leverhulme Trust. I thank Catherine A. Bradley for her valuable contributions to this paper.

${ }^{1}$ On this, see in particular Sylvia Huot, Allegorical Play in the Old French Motet: The Sacred and Profane in Thirteenth-Century Polyphony (Stanford, CA: Stanford University Press, 1997).

2 See Catherine A. Bradley, 'Re-workings and Chronological Dynamics in a Thirteenth-Century Latin Motet Family', Journal of Musicology 32 (2015):153-97; eadem 'Contrafacta and Transcribed Motets: Vernacular Influences on Latin Motets and Clausulae in the Florence Manuscript', Early Music History 32 (2013): 1-70, eadem, 'New Texts for Old Music: Three Early Thirteenth-Century Latin Motets', Music \& Letters 93 (2012): 149-69.

${ }^{3}$ See, for example, Gaël Saint-Cricq, 'A New Link Between the Motet and Trouvère Chanson: The Pedes-cum-cauda Motet', Early Music History 32 (2013): 179-223,
} 
Moreover, the history of the motet is changing incrementally as, despite their anonymity, motets are increasingly treated not en masse, or in large taxonomical blocks, but as individual works, highly fashioned by skilled composers, deeply embedded in complex networks of other voices, musical works, genres, and poetry. The present article seeks to further the discussion of the diversity of the motet in the long thirteenth century by considering a specific, rather unusual example of motetrelated materials in a songbook. The songbook in question has two notable features: Oxford, Bodleian Library Douce 308 (hereafter D308) is unnotated and organised by genre. ${ }^{4}$ These features mean that the source has been of limited use as a witness to the history of motets, and what attention it has been paid has been directed specifically at the seventh of these eight genre sections, which contains an extensive collection of song-like motets (albeit without musical notation), with no indication of tenors, and nearly all in the refrain-bounded motet form known as the motet enté ${ }^{5}$ The example discussed here, however, is not found in the motet subsection of the songbook, but rather in the subsection that contains pastourelles. Like some of the other motets in D308, its relation to the 'same' motet in other sources shows considerable differences, leading to questions about the function of the version in D308 and its chronology relative to the other versions of the work. This article will present these differences and consider their implications.

\section{$<$ INSERT EXAMPLES 1 AND 2 NEAR HERE>}

idem, 'Motets in Chansonniers and the Other Culture of the French Thirteenthcentury Motet', in A Critical Companion to Medieval Motets, ed. Jared Hartt (Woodbridge, Suffolk: Boydell and Brewer, 2018): 225-42; see also Elizabeth Eva Leach, 'The Genre(s) of Medieval Motets', in A Critical Companion to Medieval Motets, ed. Jared Hartt (Woodbridge, Suffolk: Boydell and Brewer, 2018): 15-42, and Matthew P. Thomson, 'Building a Motet around Quoted Material: Textual and Musical Structure in Motets based on Monophonic Songs', in A Critical Companion to Medieval Motets, ed. Jared Hartt (Woodbridge, Suffolk: Boydell and Brewer, 2018) ): 243-60.

${ }^{4}$ The best current description is found in Alison Stones, Gothic Manuscripts 12601320, 2 vols., A Survey of Manuscripts Illuminated in France (London: Harvey Miller, 2013-2014), vol. 2, part 1, pp.41-53 (catalogue no.IV-10).

${ }^{5}$ See Saint-Cricq, 'Motets in Chansonniers and the Other Culture of the French Thirteenth-century Motet'; see also Ardis Butterfield, 'Enté: A Survey and ReAssessment of the Term in Thirteenth and Fourteenth-Century Music and Poetry', Early Music History 22 (2003): 67-101. 


\section{Pastourelle No.56 and its Motet Relations}

The first stanza of pastourelle no.56 (hereafter P56) in D308 is identical with the motet voice, 'Hé bergier' (MV657; for text and translation, see Example 1). ${ }^{6}$ This voice, 'Hé Bergier', is found as the motetus part of two, three, and four-voice motets in several of the main motet sources (for details, see Example 2), which will be discussed below. ${ }^{7}$ The 'je' of the text is a knight who addresses a shepherd informally (using 'tu'), saying 'Hey shepherd, I am so envious of you, because you have such a good life compared to me'. The knight claims he has never been able to find loyalty or faith even where he has deserved it, and yet the shepherd, who, the knight alleges, has 'not served Love in any way' is seen to be rejoicing in it and is boasting 'in the alder grove, down in the alder grove, in the arms of your beloved'. ${ }^{8}$ These final lines of the first stanza, in which the knight ventriloquizes the boasting song of the shepherd, is classified by modern scholarship as a refrain. ${ }^{9}$ It is one that

\footnotetext{
${ }^{6} \mathrm{MV}$ (standing for 'motet voice') is followed by the number that identifies the text in the catalogues of Friedrich Ludwig, Repertorium organorurn recentioris et motetorum vetustissimi stili (Halle: Niemeyer, 1910) and Hendrik van der Werf, Integrated Directory of Organa, Clausulae, and Motets of the Thirteenth Century (Rochester, NY: by the author, 1989). RS gives the number of the poem in the catalogue of Hans Spanke, G. Raynaud's Bibliographie des altfranzösische Liedes, neu bearbeitet und ergänzt (Leiden: Brill, 1955). The other manuscript sigla used here relate to RISM sigla as follows:
}

Ba. $D$-BAs Lit. 115

Cl. F-Pn n.a.f.13531

D308. GB-Ob Douce 308

Mo. F-MO H 196.

StV. F-Pn lat. 15139.

TrouvN. F-Pn fr.845

TrouvP. F-Pn fr.847

TrouvT. F-Pn fr.12615

TrouvX. F-Pn fr.1050

W2. $\quad D-W$ Cod. Guelf. 1099 Helmst.

7 In its four-part version, this motet has been discussed extensively in Christopher

Page, 'Around the Performance of a Thirteenth-Century Motet', Early Music 28 (2000): 343-357.

8 The variant 't'amie', found only in the first stanza of the version in D308, does not need correcting, since the knight is still addressing the shepherd and is therefore adjusting the pronouns of his reported speech to make it fit. Such flexibility in otherwise unchanging refrains is relatively common in pastourelle texts.

9 It is vdB659; the number refers to the listing in Nico van den Boogaard, Rondeaux et refrains du XIle siècle au début du XIVe, Série D: Initiation, textes, et documents 
is found, however, only in this text, albeit in both its motet and pastourelle versions, which makes it a 'unique refrain'. ${ }^{10}$

If the P56 version of this text did not survive, the classification of the refrain as a refrain would rely on the fact of it being marked, functionally and generically, by its terminal positioning and repeated verbal phrasing. However, P56 is a two-stanza song with an unchanging refrain (a 'chanson à refrain'), which confirms the status of the refrain as a refrain, albeit a different kind from the refrains ordinarily found in motets, which are typically non-stanzaic. Motet refrains, if intertextual, are quotations found elsewhere or, if (as more often) unique, are quotation-like in function, positioning, and verbal content. Nonetheless, this refrain, like all the refrains operating here function as refrains and exhibit typical refrain-like formal and textual markers, whether or not they are unique (as in MV657), intratextual (as in the chanson à refrain of P56), or intertextual.

The second stanza of P56, which is voiced by the shepherd, re-uses the refrain (which is one way to confirm the status of a refrain as such), and in fact explains it as an 'amorous pleasantry [donoi]' he was singing to himself for his own amusement. The shepherd accuses the knight of knowing nothing about him, his service to love, or his boasting. The knight has based his vile accusation purely on a song that he has wrongly taken as truth when the shepherd was just singing for fun; ironically, the knight has committed base speech ('vilonie', 'felonie') because he has incorrectly read (in fact, heard) the lower-class character's courtly 'donoi' as a true boast. The 'donoi' itself is a refrain because it is re-used within a single stanzaic refrain-song (where it is confirmed as a refrain-a short snippet of courtly poetry, sung by courtiers-precisely at the point the shepherd sings it, proving his point). ${ }^{11}$ While it is

(Paris: Klincksieck, 1969).

10 On the issue of whether such non-concordant refrains are chimerical or real, see, for example, Mark Everist, French Motets in the Thirteenth Century: Music, Poetry and Genre (Cambridge: Cambridge University Press, 1994), 54-71; Butterfield, 'Enté'; Jennifer Saltzstein, The Refrain and the Rise of the Vernacular in Medieval French Music and Poetry (Woodbridge, Suffolk, UK: Boydell and Brewer, 2013), 834.

11 The function of refrains as stand-alone musico-poetic items has to be deduced from their interpolation into narratives. The verisimilitude of the Tournoi de Chauvency, a narrative poem bound with the songbook in D308 chronicling a multi- 
possible that it was a more widely circulated 'intertextual refrain', no evidence survives of such wider use; in any case, it is plausible it was written for this particular text, not least because it seems retrospectively to generate the versification of the rest of the stanza in the parameters of rhyme types and syllable count.

As seen in Example 2, the first stanza of P56 is widely transmitted as the entire text of a motetus voice in a variety of motet contexts (nos.1-5); the melody associated with this stanza in notated sources is in turn found transcribed into textless notation with its French incipit in the margin (no.7), as well as being copied with an alternative Latin text (no.8). When transmitted within a three-part motet, 'Hé bergier' (MV657) is combined with 'Par un matinet' (MV658) as the triplum. The first person singer in 'Par un matinet' is the voice of a different knight who has clearly overhead the same shepherd's song. Like the first knight, he hears it as a factual boast and deems it folly, because such love is base. This second knight then claims that he loves more loyally than anyone, and, 'because a beautiful lady loves me, I ask for nothing more'. This text is also a refrain, since it is found in two other motet voices, where it has similar text and melody. ${ }^{12}$ The three-part version of the motet is found in $\mathbf{B a}$, and in the fifth fascicle of Mo (no.145), where the motetus (but not the triplum) is incompletely copied. ${ }^{13}$

day tournament festivity that took place in 1285 , implies courtiers used refrains to accompany their movement between tournament field and castle, as well as for playful exchange, often involving dancing, after dinner.

12 It is found among the two-part motets in Mo fascicle 6, split between the beginning and end of the upper voice of Mo no.213, which is also on the EIUS tenor in the reverse rhythm of the tenor associated with 'Hé bergier'. It also occurs at the end of 'Cest quadruble sans reison' (MV799), the quadruplum of Mo no.30, a four-part piece in fascicle 2, where it occurs simultaneously with a refrains in the other voices in which a lover asking when he will sleep 'between the sweet arms' of his lady and a lady berates the baseness of a lover whose embrace was wicked. On refrains found only within the motet repertoire as a special subcategory of intertextual refrain, see Saltzstein, The Refrain and the Rise of the Vernacular in Medieval French Music and Poetry, 60-8.

${ }^{13}$ Although the page (f.197r) was set up with enough space for the entire text, the text scribe has omitted line 8 and filled out what is now too much space with a big gap after 'toi' at the end of line 10 (middle of third system) and an even bigger gap after 'braz' in line 12 (middle of fourth system). Nonetheless, the single final syllable '-mie' sits alone at the start of the fifth system and is followed by an extravagant blue decoration to occupy the rest of the space and, presumably, to instruct the scribe ruling the staves that the entire width of the page should be ruled. The music scribe stopped copying the melody after getting to the point where the exemplar had line 8, 
While two-part versions, with only the motetus melody and the EIUS tenor, do exist-two of them-neither transmits the French motetus text. The version in W2 (f.175v-176r) has a sacred Latin text, which nonetheless replicates the versification pattern of the French text and seems to belong to a group of pieces in this source that represent later Latin re-textings of French originals. ${ }^{14}$ This text name-checks Samson and Delilah without further elaboration, which provides an implicit moral judgement on the French motetus text, and, indeed, on the several upper-voice texts of the vernacular motet, since Samson's strength was undermined by being in the arms of his beloved, suggesting that the original text still lurks behind its contrafact. The version of the melody in the two-part arrangement in score in StV is labelled in the margin with the incipit of the French text 'Hé bergier', but is otherwise textless. This is, as Fred Büttner has shown, a transcription of the motet into modal ligatures facilitated by the removal of its text, here, clearly, the French text that is most commonly found with this melody and seems likely to have been its original text. ${ }^{15}$

A four-part version exists in two sources: $\mathbf{C l}$ and in the second fascicle of Mo. Both these copies apparently view the 'Par un matinet' voice, which had been the triplum of the three-part version, as a quadruplum, placing it first in the sequence of voices presented. In the triplum position of these four-part versions, that is, copied in second position in the sources, is a new text, 'Hé sire' (MV659), which, unlike the other two texts, gives voice to the shepherd (see again Example 1 for text and translation). This new text has been slotted into the triplum position, seemingly bumping the triplum found in the three-part versions of the motet up into the quadruplum position. ${ }^{16}$ This 'Hé sire' text seems an especially fitting riposte to the motetus: it echoes the opening 'Hé bergier' with 'Hé sire', thus addressing the knight directly, and then starts with a specific reference to him having boasted that he has

realizing there was a line of text missing in Mo as compared to the exemplar. Perhaps the scribe intended to come back (there would have been room to supply the missing line after the end of this voice part) but never got round to it. 14 On this text in particular, see Fred Büttner, Das Klauselrepertoire der Handschrift Saint-Victor (Paris, BN, lat. 15139): Eine Studie zur mehrstimmigen Komposition im 13. Jahrhundert (Lecce: Milella, 2011), 230; on W2 in general, see Bradley, 'Contrafacta and Transcribed Motets', passim.

15 Büttner, Das Klauselrepertoire der Handschrift Saint-Victor, 228-32.

16 See ibid., 231. 
'deserved courtesy and loyalty'. The shepherd denies the knight's allegation that he has never served love loyally as a false reproach. He has never not served love loyally: 'no one has ever felt the pains of love as I feel them'. Once more, the closing words of this text is a refrain, this time one that circulated more widely, including outside the motet repertoire in a song with changing refrains (a 'chanson avec des refrains'), as well as a refrain song (a 'chanson à refrain'). ${ }^{17}$ As Example 1 shows, it is this triplum text which bears an interesting relation to the second stanza of the D308 pastourelle: the 'Hé sire' triplum is not the same text as the second stanza of P56, but it apparently voices the same individual and, like the second stanza, this shepherd 'je' strongly refutes the motetus knight's accusation. This similarity of content goes beyond what might be expected from the general generic framing of the pastourelle, which actually rarely stages a dialogue between a knight and a shepherd, especially on the rather abstract topic of base versus noble love and without any explicit mention or presence of a shepherdess. While there are virtually no precise verbal echoes between the text, this can be explained by the necessity of replicating the versification of MV657, which is very different from that of MV659 (incidentally lending additional evidence to the second stanza being created from MV659 rather than vice versa, when versification would have been unconstrained and more verbal echoes might have been expected, even if the poetry were to be rewritten for the sake of the new musical setting). In effect, the two-stanza text of P56 presents the two simultaneous texts of motetus and triplum as found in the four-voice motet, with their contrasting refrains, as a sequential dialogue, sharing a single refrain.

As well as serving as the triplum of the four-part version of the motet found in Mo and $\mathbf{C l}$, however, the 'Hé sire' text appears in $\mathbf{W} \mathbf{2}$ as the motetus of a two-part motet that uses precisely the same tenor in the same rhythmicization as the motetus 'Hé bergier'. While it could appear that this two-part motet is a curious reduction of the four-part motet to tenor and triplum, it seems more likely that the four-part motet was

17 This refrain, vdB1424, is found in two of the six surviving copies of one widely copied chanson avec des refrains, 'L'autrier par un matiniet / Erroie' (RS962; copies in TrouvN and TrouvP), in refrain song by Robert de Reims found only in TrouvX, 'L'autrier de jouste un rivage' (RS35), and in a longer poem with interpolated refrains, D'amours et de jalousie preserved only in F-Pn fr.19152, f.110v-112v. None of these four sources has musical notation. 
created by inserting the motetus of another motet 'Hé sire / EIUS' which happened to be on precisely the same tenor into the text of the three-part motet 'Par un matinet'/'Hé bergier'/EIUS. This is not just because W2 is an earlier source than Mo and $\mathbf{C l}$, since source chronology is sometimes at odds with musical chronology for motets. ${ }^{18}$ Both the melodies of 'Hé sire' and 'Hé bergier' have a similar contrapuntal profile in terms of overall range and of sonorities at major points of articulation (beginning of the piece shown in Example 3, end of the piece, and the start of individual perfection groups); they also share rests. 'Hé sire' frequently duplicates pitches already present in the motetus. The original triplum of the three-part version, 'Par un matinet', by contrast, is mainly differentiated from the 'Hé bergier' motetus, with pitch duplication between these two parts relatively minimal (see Example 4, giving all four parts for the last eight perfections of the first tenor cursus). And these two upper voices in the three-part motet have overlapping phrases except just before the refrain, which further differentiates the two voice parts. I am not the first to suggest that the motetus voice 'Hé bergier' and the apparent triplum that is only found either in the four-part version, or on its own with tenor ('Hé sire'), were not originally intended to be performed simultaneously. Büttner, whose point of departure is also the D308 text, has proposed that the two motet voices 'Hé bergier' and 'Hé sire', were originally intended to be a pair of separate motets on the same tenor presenting the knight's speech and the reply of the character he addresses. ${ }^{19}$ This, he explains, is why there are barely acceptable dissonances between 'Hé sire' and the other voices, and why this voice part only appears in the four-voice version, where such dissonances are more acceptable. ${ }^{20}$

<INSERT EXAMPLES 3 and 4 NEAR HERE>

\footnotetext{
18 This is one of the basic arguments in Bradley, 'Contrafacta and Transcribed Motets'; the conclusions reached in Gaël Saint-Cricq, 'Transmitting a Compositional Process: Two Thirteenth-Century Motets', Musica Disciplina 58 (2013), 327-49, at 344 give a further examples of the lack of congruence between the relative dates of manuscripts and the pieces contained in them.

${ }^{19}$ Büttner, Das Klauselrepertoire der Handschrift Saint-Victor, 231. Somewhat puzzlingly, Büttner (p.230) sees 'Hé sire' as the reply of a shepherdess, as opposed to the D308 text's second stanza's shepherd, although this is not supported by the text.

20 Ibid., 231.
} 
The only argument against the idea that the motetus voice 'Hé bergier' and the fourpart version's triplum 'Hé sire' were originally separate motetus voices in separate motets might be the presence of textual links between what the knight says and what the shepherd replies. Büttner's proposal that they were designed to go together, but in sequential performance of a motet pair on the same tenor, rather than a two parts in the same motet, makes sense of this feature. Collections of motets in songbooks tend to exhibit small runs of motets on the same tenor, hinting that the smaller sources, perhaps bifolio, that served as ephemeral records and possibly exemplars, collected motets in this way. ${ }^{21}$ In Büttner's scenario, the paired motet performances would resemble the performance of P56 in having the two characters perform separately, although they would not, as in the pastourelle, parallel their accusation and answer by singing them to the same tune in the same versification. Instead, the paralleling would be provided more discreetly by their shared length and their shared use of precisely the same double-cursus tenor, patterned rhythmically in the same way.

\section{Questions of Chronology, Comprehension, and Performance}

It is possible that some of the evidence here is lacking. It seems strange that no twopart version with the 'Hé bergier' text exists, for example, but merely the later contrafact version in W2. Nonetheless, the existence of the version in StV, a textless transcription, but cued by the French incipit, might derive from just such a two-voice version which just, by chance, no longer exists. Might there also have been, at some stage, a three-part version of the motet, which presented the dialogue as a simultaneous version of what is present in the pastourelle in sequential stanzas? That is, a version that had the motetus 'Hé bergier' and the triplum used on the fourpart version, 'Hé sire', but without the former triplum 'Par un matinet' being used as a quadruplum? Büttner rejects this idea, noting 'Hé sire' as 'hardly serious as a

${ }^{21}$ On scattered clusters in TrouvT, see Gaël Saint-Cricq, Eglal Doss-Quinby, and Samuel N. Rosenberg, eds., Motets from the Chansonnier de Noailles, Recent Researches in the Music of the Middle Ages and Early Renaissance (Middleton WI: A-R Editions, 2017), xx; on the compilation of D308 from small sources, see Robert Lug, 'Common Exemplars of $U$ and C', Schweizer Jahrbuch für Musikwissenschaft (forthcoming). 
useable triplum for the two-part underpinnings made by the EIUS-tenor and the 'Hé bergier' motetus'. ${ }^{22}$ My comments above about the level of pitch duplication between 'Hé bergier' and 'Hé sire', while used there to argue that they are in fact two separate motetus parts, would also make these parts unsatisfying in combination without the presence of a fourth voice, singing in a third pitch ambitus, to add fuller harmonic interest. I therefore concur, once more, with Büttner. And although lack of evidence is not conclusive, it may be indicative that no three-part version in this arrangement survives.

There may, however, be the trace of an attempt to copy this very three-part arrangement in the incomplete copy in $\mathbf{W} 2 .{ }^{23}$ The page on f.208v in $\mathbf{W} \mathbf{2}$ is set up for a three-part motet, the staves and text have been entered, including the large initial capitals, but the text scribe has copied the same text twice, the fundamental motetus text MV657, its incipit here spelled both times as 'E bergier', with the letter 'E' illuminated. The second text has been provided with the MV657 melody, but the staves above the first text have been left blank. While one might assume, as Ludwig did, that it should have carried the Par un matinet voice, could it instead have been intended to be 'E sire'?. ${ }^{24}$ Suggestively in a manuscript with pervasive use of ordering by initial letter, this copy is surrounded by three-part motets in which the triplum and motetus begin with the same letter: it is preceded by Dex je fui ja pres de joir / Dex je n'i puis la nuit dormir / ET SUPER, and followed by Dame de valor / Dame vostre douz regart / MANERE, so that the opening which contains $\boldsymbol{E}$ bergier / $\boldsymbol{E}$ bergier / [EIUS] is visually striking, with two letter Es on the left and two Ds on the right. ${ }^{25}$ Perhaps the scribe knew of the existence of a motet that had the texts $E$ sire / $E$ bergier / EIUS and intended this to fit the bill here, but was unable to find an

\footnotetext{
22 Büttner, Das Klauselrepertoire der Handschrift Saint-Victor, 232 'kaum ernsthaft als brauchbares Triplum für den zweistimmigen Unterbau aus "Eius"-Tenor und "E Bergier"-Motetus'.

${ }^{23}$ I thank Catherine A. Bradley for pointing out the significance of the alphabetic context here her and discussing with me the possibilities advanced in the present and following paragraph.

24 See Ludwig, Repertorium, 1/1: 201.

25 The former is additionally preceded by Noine sanz amor / Noine qi a cuer / ET SUPER where the second 'Noine' should be 'Moine', an understandable mistake (or choice?) in the context of a run of pieces with matched opening motetus and triplum letters.
} 
exemplar for it. This would support the hypothesis (advanced above on harmonic evidence) that no such three-part version was in circulation.

Furthermore, the one cursus that is entered for the tenor has two features unique for this manuscript: it has no textual label, and no space has been left for it in the regular position of last in the copying order, so that after the first five pitches, the rest is copied at the end of the (musically un-notated, incorrectly texted) 'triplum', before the start of the (musically notated, correctly texted) motetus. The space after the end of the first voice on this folio might possibly indicate that this is where the tenor was originally positioned in the exemplar, pointing to a scribe working from two independent two-voice motets that shared the same tenor and which the scribe was combining on the fly because the scribe knew that they were also to be found in combination, albeit not in this three-voice (as opposed to the four-voice) combination. Knowing that these two motetus parts on the same tenor were sometimes performed together might have prompted the $\mathbf{W} \mathbf{2}$ scribe to include them here among the three-voice motets with upper-voices starting on the same letter.

The questions about the relationship between P56 and the two motet texts that it relates to are thereby complicated further. When it seemed that both voices to which the stanzas of P56 relates were originally part of a single polyphonic piece, the question was whether the song inspired the motet or whether it was distilled from it, perhaps as a way of explaining or introducing the polytextual version. But if the voices were originally two separate motets, as seems likely, the song either inspired the composition of two motets designed to be performed in sequence or one must pre-suppose this mini motet-cycle as being reduced to a single song by composing a second stanza that would fit to the tune of the 'Hé bergier' motetus but express the sentiments of 'Hé sire'. Even if the original situation was that of two separate motets, there is no guarantee that the song was not generated after they had been combined into the four-part version.

The tacit assumption in cases where a monophonic song stanza forms one voice part in a polyphonic motet, had been to assume the priority of monophony, presumably in line with the assumed history of the motet itself, starting with a monophonic melody (chant). However, dissertations by Saint-Cricq and Matthew P. 
Thomson both note the possibility for songs to be extracted from motets, and some motets may anyway have been originally a monophonic upper-voice part (a 'monophonic motet') with the tenor retrospectively fitted to it. ${ }^{26}$

It seems unlikely, and has already been rejected by Büttner, that P56 was a preexisting pastourelle song whose pithy dialogue inspired the creation of two separate motet voices. Such a scenario would involve a composer deriving the motetus 'Hé bergier' directly from the first stanza of the pastourelle, probably (if comparable borrowing can serve as a guide) preserving its melody entirely, and either newly fixing its rhythm, or reflecting its rhythmic monophonic performance (depending on one's views on the fraught issue of trouvère rhythm, which is, thankfully, outside the scope of this article!). This composer, who knows this two-stanza pastourelle in the form of a dialogue between knight and shepherd, would then have the idea of presenting it in motet form over a Marian tenor. We would have to hypothesize that the composer wanted to preserve the sequential nature of the dialogue and thus chose to write a pair of motets, each using the same tenor. In the process the composer re-writes the poetry of the second stanza and chooses a different terminal refrain.

Such a hypothesis has elements that stretch credulity: why would the composer bother to write a new 'Hé sire' poem with a new, and very irregular verse, form? Even if it is to accommodate the new refrain, this seems a poor decision, since it removes one of the chief poetic complexities of the pastourelle, making the motet version no longer about the truth-value of song, as in the pastourelle. While the composer of 'Hé sire' might simply have been a worse poet (and better composer?) than the original pastourelle trouvère, this supposition is still doubtful. It would have been possible, arguably easier, and a way of preserving the lyric complexity of the pastourelle poem, simply to compose a new melody for the second stanza. And at

${ }^{26}$ See Gaël Saint-Cricq, 'Formes types dans le motet du XIIle siècle: étude d'un processus répétitif' (PhD thesis, University of Southampton, 2009); Matthew P. Thomson, 'Interaction between Polyphonic Motets and Monophonic Songs in the Thirteenth Century' (DPhil thesis, University of Oxford, 2016); Leach, 'The Genre(s) of Medieval Motets'; Catherine A. Bradley, 'Choosing a Thirteenth-Century Motet Tenor: From the Magnus liber organi to Adam de la Halle', Journal of the American Musicological Society 72 (2019): forthcoming. 
that point, it would have been an obvious move, in the context of the motet genre, to set the second stanza in another voice part simultaneously, as a triplum. ${ }^{27}$

The alternative - and, to my mind, far preferable - scenario is one in which the pastourelle derives from the motet or motets, that is, the song is some kind of response to the pre-existence of 'Hé bergier' and 'Hé sire'. Again, Büttner has already proposed this chronology, although purely on the grounds of the late date of D308 itself, which is reasoning that can be shown to be problematic in the chronology of motet manuscripts in general, and has been explicitly rejected for D308 in particular. ${ }^{28}$ I therefore reject Büttner's rationale, while feeling inclined towards his conclusion. ${ }^{29}$ The question then becomes whether the composer of the pastourelle version knew the two motetus texts in separate (but connected) motets, or only in the four-part motet version. The latter is not impossible, although the former seems most likely, given that P56 shows no trace of 'Par un matinet'. ${ }^{30}$ If 'Hé bergier' and 'Hé sire' were two separate motets being performed sequentially, a sequence of stanzas replicates that situation most closely, keeping the dialogue aurally graspable. The new 'Hé sire' text is now forced to replicate the versification of the motetus poem and, because the refrain is so integrated into the versification of the 'Hé bergier' stanza, to share its refrain. In the process the second stanza loses some of its elements of direct reply, but gains a new interpretation of the fixed refrain and the knight's original understanding of it, making for a more complex interaction

27 The potential that the 'Par un matinet' triplum originally carried the 'Hé sire' text in a three-part version now lost to us is not untenable only because it would be unprecedented but also because the phrase structure of the former and the versification of the latter are antithetical.

28 See the comments in Bradley, 'Contrafacta and Transcribed Motets', 70; on D308 see Leach, 'The Genre(s) of Medieval Motets'. Büttner also sees the P56 second stanza as newly accentuating the pastourelle character of the motet by giving the shepherd's reply. For him, this is different from the motet version of 'Hé sire', which in his view presents the voice of the shepherdess (see n19 above).

${ }^{29}$ Büttner, Das Klauselrepertoire der Handschrift Saint-Victor, 228-32. I would also argue with Büttner's wish to see the alternative Latin text as unrelated to the French motetus (see my comments above), although, again, I agree with him that it is later than the French version.

30 The latter would lead to the monophonic song being seen as a way of presenting the polyphony and polytextuality of the motet in a music comprehensible way, akin to the performance of individual motet voices separately suggested in Page, 'Around the Performance of a Thirteenth-Century Motet'. 
between the two characters, together with a nuanced poetic reflection of the interrelations of poetry, song, courtliness, class, and truth.

\section{<INSERT EXAMPLE 5 NEAR HERE>}

One aspect of the versification in the second stanza suggests that the pastourelle writer not only knew a melody but that it was probably the melody present in the motet. Line 4 is four syllables long in stanza I, but only three in stanza II. This is because the unstressed '-e' of the '-ie' rhyme of line 3 is elided by the opening vowel of line 4 in stanza I, but stanza II's line 4 starts with a vowel (compare the underlay of these two lines in each stanza in Example 5). This kind of procedure is found in motet poetry, which is not bound by considerations of syllabic regularity because it is non-stanzaic, but is not typical in stanzaic songs. ${ }^{31}$ The second stanza regularizes the versification by preventing the elision of line 3's rhyme word's unstressed '-e' by starting the following line with a consonant ('Car'). This necessitates line 4 being a syllable shorter than the corresponding line in the first stanza. ${ }^{32}$

Most intriguing here is the plausible suggestion, first voiced by Büttner, that there existed two separate but linked motets providing a dialogic mini-cycle. The resulting imagined sequential performance of two motets on the same double-cursus tenor brings together various genres under the motet umbrella, including the pastourelle, the agonistic dialogue (hinting at the jeu-parti) and, because of the changing terminal refrains, the chanson avec des refrains. This generic heterogeneity in turn proposes social hybridity, with clerical and courtly genres, particularly those associated with the borderlands from Arras to Lorraine. Nonetheless, without the testimony of no.6 in Example 2, the two-part 'Hé sire' motet in $\mathbf{W} \mathbf{2}$, this conclusion would be rather more tentative, being forced to rely on the contrapuntal evidence, when there is still insufficient analytical study of the interaction of thirteenth-century motet counterpoint, voice function, and dissonance treatment. Better understanding of these features

\footnotetext{
${ }^{31}$ See Bradley, 'Contrafacta and Transcribed Motets', 18fn57 for other examples. 32 Similar differences occur between the original and later textings of Error popularis and Fole acostumance (see ibid., 8-20, especially music example 1, pp.12-15), where they are contrafacts in different languages. But this technique can be seen as analogous to writing another stanza to an existing motet text, even in the same language.
} 
might make it possible, in cases where no second motetus survives in a two-part version, to ask whether other such performance pairings exist.

The further and fuller investigation of whether the repertoire contains traces of other such motet pairs is beyond the scope of this article but one might legitimately ask whether the attested phenomena of motets copied separately in some sources and together (as if a single piece) in others, and the clustering pieces related by tenor source in close proximity, might be related to the sort of pairing suggested here. ${ }^{33}$ Saint-Cricq has recently suggested that a run of so-called Kurzmotetten copied in two songbooks form a musical and dramatic dialogue in which 'the cyclic aspect of the set is obvious not only on the basis of similar compositional procedures, but also on the basis of the dramatic potential of their successive presentation, their unity of register, theme, and vocabulary, their homogeneous musical sonorities, their ties to literature, and their layout'. ${ }^{34}$

There is already good indication that connections between motets go beyond the way in which they have most often been traced, that is, by comparing different versions (that is, with contrafact texts or variant number of voice parts) of the 'same' motet setting. Wider links have be seen, for example, in different motets that use the same tenor source, which can show shared musical material between the upper voices of different motets. ${ }^{35}$ Saint-Cricq has added formal upper-voice modelling to

${ }^{33}$ See, for example Anna Kathryn Grau, 'Thematic Clusters and Compilational Strategies in Montpellier 8', in The Montpellier Codex, The Final Fascicle: Contents, Contexts, Chronologies, edited by Catherine A. Bradley and Karen Desmond (Woodbridge, Suffolk: Boydell, 2018), 124-31 on the case of Balam inquit (MV594)/ Balam inquit (MV594) / BALAAM and Huic ut placuit (MV595) / Huic ut placuit (MV595) / [HUIC MAGI] and the surrounding cluster in Mo.

${ }^{34}$ Saint-Cricq, et al., eds., Motets from the Chansonnier de Noailles, xxviii. 35 In in particular chapters 1, 3, and 5 of Catherine A. Bradley, Polyphony in Medieval Paris: The Art of Composing with Plainchant (Cambridge: Cambridge University Press, 2018): Bradley argues strongly for shared modelling and conventions as well as a general mutual awareness of other motets within tenor families. See also other studies tracing shared tenor sources, for example, Dolores Pesce, 'Beyond Glossing: The Old Made New in Mout me fu grief / Robin m'aime / Portare,'in Hearing the Motet: Essay on the Motet of the Middle Ages and Renaissance, edited by Dolores Pesce (Oxford: Oxford University Press, 1991), 2851 and eadem, 'Montpellier 8 PORTARE Motets and Tonal Exploration' in The Montpellier Codex, The Final Fascicle: Contents, Contexts, Chronologies, edited by Catherine A. Bradley and Karen Desmond (Woodbridge, Suffolk: Boydell, 2018), 
this list of motet-motet connections in his discussion of two motets whose motetus parts have song-like AAB form, borrowed song materials, and shared musical material despite not sharing a tenor source (although their tenors 'exhibit similar melodic patterns'). ${ }^{36}$

The relationship between 'Hé sire' and 'Hé bergier' advanced above correlates with these being the only two motets on this tenor to share this particular version of the tenor melody, sharing both its length of 30 pitches and this particular tenor rhythm. ${ }^{37}$ A reasonable starting point for further work might thus be other motetus parts with identical tenor melodies (using the same portion of the chant melisma), which are also in the same repeating rhythm, or at least use repeating rhythms that share the same placement of pitches at the start of perfections. ${ }^{38}$ While I have yet to be aware of other chanson texts that combine texts from two different motet voices, an increased awareness that separate motets may potentially be in a similar kind of dialogue with one another-musically and/or textually-this possibility generates further layers to the dense intertextual meanings in which motets are already enmeshed.

233-53. For a study that additionally notes shared upper-voice traits in motets linked by tenor source; see Anne Ibos-Augé, '... Que ne dit "cief bien seans": Quoting Motets in Montpellier 8' in The Montpellier Codex, The Final Fascicle: Contents, Contexts, Chronologies, edited by Catherine A. Bradley and Karen Desmond (Woodbridge, Suffolk: Boydell, 2018), 211-30.

${ }^{36}$ Saint-Cricq, 'Transmitting a Compositional Process', 341. Notably, one of the two motets Saint-Cricq discusses is on the FLOS FILIUS EIUS tenor and becomes increasingly pastourelle-like in genre, and the other shares its opening material with a monophonic pastourelle.

${ }^{37}$ This is regardless of whether the tenor is identified as EIUS or as DOMINO.

${ }^{38}$ For example, the motetus voice 'Donés sui sans repentir' (MV683) unique in Mo (where it has the triplum 'Las, por qu'acointai' (MV682)) is sung in a motet in which the EIUS tenor is identical musically with DOMINO as used for the motetus voice 'Hyer main, trespensis d'amors' (MV750) in W2. Could both motetus parts be sung together-with or without the triplum of the Mo version-and sustain musical or poetic readings? Less exact but also potentially workable from the EIUS-tenor motets is the version of the tenor used by 'Domino fidelium' (MV753) and that for 'Mater virgo' (MV691), which are the same length and place the same pitches at the start of perfections (albeit the latter has the initial rhythm of breve-long-breve and the former long-breve-long). It should be noted that the latter motetus quotes the melody (but not the text) of the terminal refrain in 'Hé sire'; see Leach, 'The Genre(s) of Medieval Motets', 40. 


\section{BIBLIOGRAPHY}

Bradley, Catherine A. "Choosing a Thirteenth-Century Motet Tenor: From the Magnus liber organi to Adam de la Halle." Journal of the American Musicological Society 72, no. 2 (2019): forthcoming.

. Polyphony in Medieval Paris: The Art of Composing with Plainchant. Cambridge: Cambridge University Press, 2018.

. "Contrafacta and Transcribed Motets: Vernacular Influences on Latin Motets and Clausulae in the Florence Manuscript." Early Music History 32 (2013): 170.

. "New Texts for Old Music: Three Early Thirteenth-Century Latin Motets." Music \& Letters 93 (2012): 149-69. doi:10.1093/ml/gcs034.

. "Re-workings and Chronological Dynamics in a Thirteenth-Century Latin Motet Family." The Journal of Musicology 32, no. 2 (2015): 153-97.

Butterfield, Ardis. "Enté: A Survey and Re-Assessment of the Term in Thirteenth and Fourteenth-Century Music and Poetry." Early Music History 22 (2003): 67101.

Büttner, Fred. Das Klauselrepertoire der Handschrift Saint-Victor (Paris, BN, lat. 15139): Eine Studie zur mehrstimmigen Komposition im 13. Jahrhundert. Lecce: Milella, 2011.

Everist, Mark. French Motets in the Thirteenth Century: Music, Poetry and Genre. Cambridge: Cambridge University Press, 1994.

Grau, Anna Kathryn. "Thematic Clusters and Compilational Strategies in Montpellier 8." Chap. 7 In The Montpellier Codex, The Final Fascicle: Contents, Contexts, Chronologies, edited by Catherine A. Bradley and Karen Desmond. 121-36. Woodbridge, Suffolk: Boydell.

Huot, Sylvia. Allegorical Play in the Old French Motet: The Sacred and Profane in Thirteenth-Century Polyphony. Figurae: Readings in Medieval Culture. Stanford, CA: Stanford University Press, 1997.

Ibos-Augé, Anne. "... Que ne dit 'cief bien seans': Quoting Motets in Montpellier 8." Chap. 8 In The Montpellier Codex, The Final Fascicle: Contents, Contexts, Chronologies, edited by Catherine A. Bradley and Karen Desmond. 211-30. Woodbridge, Suffolk: Boydell, 2018.

Leach, Elizabeth Eva. "The Genre(s) of Medieval Motets." Chap. 1 In A Critical Companion to Medieval Motets, edited by Jared Hartt. 15-42. Woodbridge, Suffolk: Boydell and Brewer, 2018.

Ludwig, Friedrich. Repertorium organorurn recentioris et motetorum vetustissimi stili. Halle: Niemeyer, 1910.

Lug, Robert. "Common Exemplars of $U$ and C." Schweizer Jahrbuch für Musikwissenschaft tbc (2019): forthcoming.

Page, Christopher. "Around the Performance of a Thirteenth-Century Motet." Early Music 28 (2000): 343-57.

Pesce, Dolores. "Montpellier 8 PORTARE Motets and Tonal Exploration." Chap. 9 In The Montpellier Codex, The Final Fascicle: Contents, Contexts, Chronologies, edited by Catherine A. Bradley and Karen Desmond. 233-53. Woodbridge, Suffolk: Boydell, 2018.

. "Beyond Glossing: The Old Made New in Mout me fu grief / Robin m'aime / Portare." In Hearing the Motet: Essay on the Motet of the Middle Ages and Renaissance, edited by Dolores Pesce. 28-51. Oxford: Oxford University Press, 1991. 
Saint-Cricq, Gaël. "Formes types dans le motet du XIIle siècle: étude d'un processus répétitif." PhD thesis, University of Southampton, 2009.

. "Transmitting a Compositional Process: Two Thirteenth-Century Motets." Musica Disciplina 58 (2013): 327-49.

. "A New Link Between the Motet and Trouvère Chanson: The Pedes-cumcauda Motet." Early Music History 32 (2013): 179-223. doi:10.1017/S0261127913000077.

_. "Motets in Chansonniers and the Other Culture of the French Thirteenthcentury Motet." Chap. 11 In A Critical Companion to Medieval Motets, edited by Jared Hartt. forthcoming. Woodbridge, Suffolk: Boydell and Brewer, 2018.

Saint-Cricq, Gaël, Eglal Doss-Quinby, and Samuel N. Rosenberg, eds. Motets from the Chansonnier de Noailles. edited by Rebecca Maloy, Recent Researches in the Music of the Middle Ages and Early Renaissance. Middleton WI: A-R Editions, 2017.

Saltzstein, Jennifer. The Refrain and the Rise of the Vernacular in Medieval French Music and Poetry. Gallica. Edited by Sarah Kay. Vol. 30, Woodbridge, Suffolk, UK: Boydell and Brewer, 2013.

. "Wandering Voices: Refrain Citation in Thirteenth-Century French Music and Poetry." PhD thesis, University of Pennsylvania, 2007.

Spanke, Hans. G. Raynaud's Bibliographie des altfranzösische Liedes, neu bearbeitet und ergänzt. Leiden: Brill, 1955.

Stones, Alison. Gothic Manuscripts 1260-1320. A Survey of Manuscripts Illuminated in France. Edited by J. J. G. Alexander and Christian Heck2 vols London: Harvey Miller, 2013-2014.

Thomson, Matthew P. "Building a Motet around Quoted Material: Textual and Musical Structure in Motets based on Monophonic Songs." In A Critical Companion to Medieval Motets, edited by Jared Hartt. forthcoming. Woodbridge, Suffolk: Boydell and Brewer, 2018. . "Interaction between Polyphonic Motets and Monophonic Songs in the Thirteenth Century." DPhil, University of Oxford, 2016.

van den Boogaard, Nico. Rondeaux et refrains du XIle siècle au début du XIVe. Série D: Initiation, textes, et documents. Paris: Klincksieck, 1969.

van der Werf, Hendrik. Integrated Directory of Organa, Clausulae, and Motets of the Thirteenth Century. Rochester, NY: by the author, 1989. 
Die Online-Angebote der Wolfenbütteler Digitalen Bibliothek der Herzog August Bibliothek (http://digbib.hab.de ) sind urheberrechtlich geschützt und unterliegen Nutzungsrechten. Soweit nicht anders vermerkt, stehen sie unter einer Creative Commons Namensnennung-Weitergabe unter gleichen Bedingungen 3.0 Deutschland Lizenz (CC BY-SA).

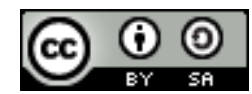

Unter diese fallen online frei verfügbare Imagedigitalisate, Strukturdaten, Volltexte, Daten aus Datenbanken (in der über OAl abfragbaren Form), Ton- und Videodokumente sowie aktuelle Publikationen. Bitte beachten Sie, dass für über die Webseiten der Herzog August Bibliothek angebotene Dokumente Dritter andere Rechte gelten können.

\section{Erläuterung}

Die Online verfügbaren digitalen Angebote der Wolfenbütteler Digitalen Bibliothek stehen allen Interessierten weltweit frei unter einer CC BY-SA Lizenz zur Nutzung zur Verfügung. Neben den in http://creativecommons.org/licenses/by-sa/3.0/de/legalcode ausgeführten allgemeinen Einschränkungen ist bei einer Nachnutzung Voraussetzung, dass a) der Urheber in der nachfolgend beschriebene Form genannt ist und dass $b$ ) das Angebot unter den gleichen Bedingungen, $d$.h. vor allem frei und unentgeltlich, erfolgt.

a) Bei der Namensnennung (BY) ist Folgendes zu beachten (vgl. CC BY-SA, Abschnitt 4.a und 4.c). In Digitalisaten angebrachte Herkunftsnachweise - typischerweise die Fußleiste - dürfen als Nachweis nicht entfernt werden. ${ }^{1}$ Zugleich muss auf der Angebotsseite an geeigneter Stelle, in jedem Fall aber innerhalb der Domain des Angebotes ein Nachweis in der folgenden Form angebracht werden: Sofern ein eigener persistenter Link (PURL, URN, etc.) verwendet wird, muss der persistente Link der Wolfenbütteler Digitalen Bibliothek über, unter oder neben dem eigenen persistenten Link stehen.

Im Druck:

\section{Herzog August Bibliothek Wolfenbüttel $\left\langle\left[\right.\right.$ Persistent URL $\left.\left.{ }^{2}\right]\right\rangle$}

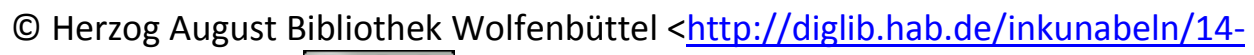
astron/start.htm> @) (1) (-)

oder

(c) HAB Wolfenbüttel: 14 Astron. <http://diglib.hab.de/inkunabeln/14-astron/start.htm> (c) (i) (2)

\footnotetext{
${ }^{1}$ Beigefügte Maßtäbe unterliegen nicht dieser Beschränkung und dürfen entfernt werden.

${ }^{2}$ Zum Zitieren Wolfenbütteler Digitalisate s.: http://diglib.hab.de/?link=033
} 
Im Internet (HTML Quelltext):

(C) Herzog August Bibliothek Wolfenbüttel \&lt;<a href="[Persistent URL]">Persistent URL</a>\&gt;

oder

(C) HAB Wolfenbüttel \&lt; <a href="[ Persistent URL]">[Signatur] $</ a>\& g t ;$ (c) () ()

Z.B. Herzog August Bibliothek Wolfenb\&\#x0OFC;ttel \&lt;<a href="

http://diglib.hab.de/inkunabeln/14-astron/start.htm">14 Astron.</a> @) (i) (2)

Wenn sich auf der Seite eine zusätzliche Angabe zur Autorin oder Autor eines Beitrages findet, z.B. (C) [Autorname] ist folgende Form einzuhalten:

Im Druck:

(c) [Autorname]. Work originally published by HAB Wolfenbüttel <Persistent URL>

(c) (i) (2)

Im Internet (HTML Quelltext):

(C) [Autorname]. Work originally published by HAB Wolfenb\&\#x0OFC;ttel \&lt;<a href="[Persistent URL]">Persitent URL oder Signatur</a>\&gt;

Z.B (C) Flemming Schock. Work originally published by HAB Wolfenb\&\#x00FC;ttel \&lt;<a href=" http://diglib.hab.de/edoc/ed000155/start.htm "> http://diglib.hab.de/edoc/ed000155/start.htm </a>\&gt; (c) () () ()

b) Bei der Bereitstellung unter gleichen Bedingungen ist zu beachten, dass das Werk frei, unentgeltlich und im Geiste der Förderung der Kultur und Wissenschaften zur Verfügung gestellt werden muss. Sofern dies gewährleistet ist, ist auch eine kommerzielle Nutzung, z.B. in der Wikipedia oder einem Open Access, unter CC BY-SA publizierenden wissenschaftlichen Verlag möglich. Nicht unter diese Lizenz fallen typische kommerzielle Produkte wie Verlagszeitschriften, die Nutzer kostenpflichtig erwerben müssen, zugangsbeschränkte Online-Angebote sowie Nutzungsarten, die ausschließlich auf Werbung oder andere nicht-wissenschaftliche Zwecke zielen. Für alle zuletzt genannten Fälle muss eine kostenpflichtige Sondernutzung vereinbart werden.

Nicht frei über die Homepage der Bibliothek verfügbare Angebote unterliegen gesonderten Nutzungsregeln, die von der Auskunft der Bibliothek (auskunft@hab.de) erfragt werden können. Im Übrigen gilt die Benutzungsordnung für Landesbibliotheken und die Gebührenordnung für die Bibliotheken des Landes Niedersachsen in der jeweils gültigen Fassung in Verbindung mit dem Niedersächsischen Verwaltungskostengesetz. 


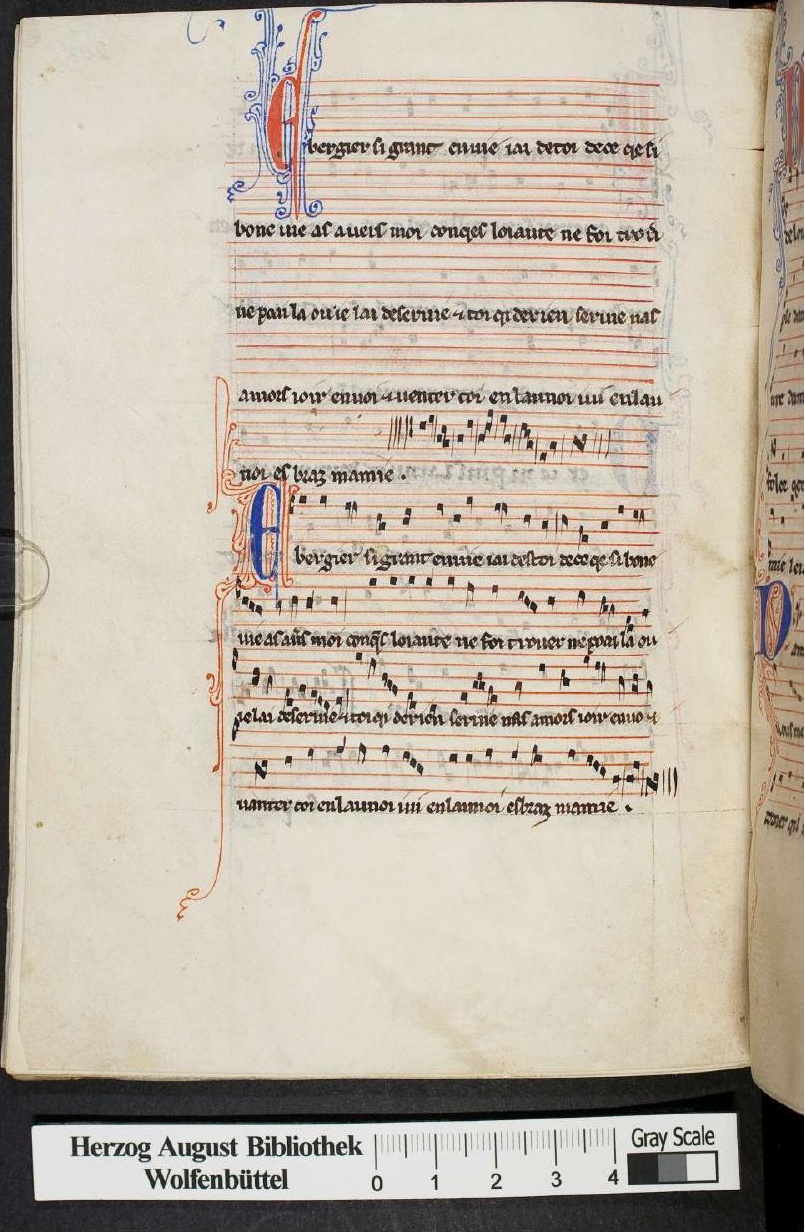

(c) HAB http://diglib.hab. de/mss/1099-helmst/start.htm?image $=00428$ 


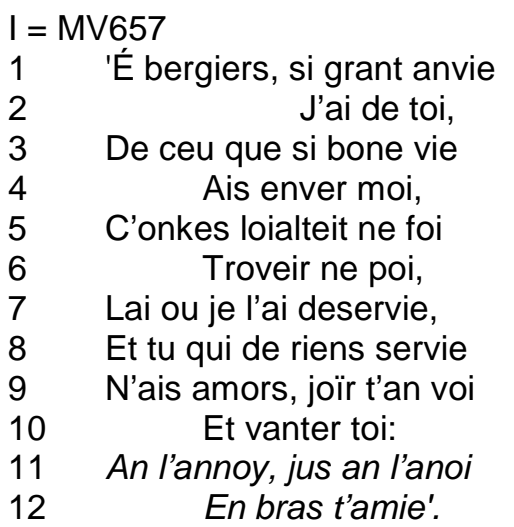

II = version of MV659

1 'Hé sire, queil vilonie

2 -Ne por coi? -

M'aveis dit, par felonie?

Car je croi*

K'ainz ne seüstes de moi

$6 \quad$ Ne ceu ne coi, 6

7 Coment j'aie amours servie; $\quad 7$

8 Non por cant ne m'an vant mie, 8

MV659 text from Mo

1 Hé sire, que voz vantes

2 Que vous avez

3 Deservie

$4 \quad$ Cortoisie

5

9 Mais an chantant m'esbanoi 9

$10 \quad$ Par teil donoi: 10

11 "K'an l'anoi, ju an l'anoi 11

12 Am brais m'amie".' 12

13

I.1. É] Le: Cl (error); 2. de] des: W2 (first text); 14

de toi] repeated Mo (fasc.5); 3. bone vie] bele 15

amie: Mo (both copies); 5. C'onkes] Onques: 16

Cl; 6. Troveir ne poi] Je ne trouviai: Ba (error); 17

Troveir ne pou: D308 (error), ne] n'i: Cl Mo 18

Et loiautez!

Tel folie

Ne dites mie

Qu'en vostre amie

Tel vilanie

Aiés trové.

Car reprové

M'aves fausement,

Qu'onques amor

Ne servi loialment:

N'onques nul ne les senti

Les maus d'amors

Si com ie sent.

(both versions); 8. tu] toi: Cl Mo (fasc.2) Ba

W2 (both texts); qui] que: Mo (fasc.2); entire line missing from Mo (fasc.5); 9. t'an] en: W2

(both texts); 12. t'amie] m'amie: Cl Mo (both

copies) Ba W2 (both texts).

II. text significantly different in all other

sources; see right-hand column version.

1. Hé sire, que] Sire qui: $\mathbf{C l}$ (error); Et sire, qi: W2; 11. Car] Et: Cl, W2; 16. N'onques nul] N'unques mes: $\mathbf{C l}$, C'onques mais: W2; 18. Si com je sent] Mes orendroit: $\mathbf{C l}$, Mes or les sent: W2.

7'a 3b 7'a 4b 7b 4b 7'a 7'a 7b 4'b 7b 4'a

7a 4a 3'b 3'b 4a 3'b 4'b 4'b 4'b 4c 4c 5d 4e 2e $6 d 7 \times 4 e 4 d$

$a=-i e ; b=-o i$

$a=-e z ; b=-i e ; c=-e ́ ; d=-e n t ; e=$ or $; x=-i$

\section{Translations}

I

'Hey shepherd, I am so envious of you, because you have such a good life compared to me, since I can never find loyalty or faith where I have deserved it, and I see you, who have not served Love in any way, rejoicing in it and boasting in the alder grove, down in the alder grove, in the arms of your beloved.'

II

\footnotetext{
${ }^{*}$ The apparent hypometric line here is explained by the lack of elision from the
}

preceding line compared to the first stanza; see Example 4 below. 
'Hey sire, what a vile thing —and for what? —have you said to me out of nastiness? Because I know that you don't know such a thing about me-neither this nor that—how I might have served love; nor have I ever boasted at all, but have enjoyed myself in singing by means of this amorous pleasantry: "in the alder grove, down in the alder grove, in the arms of my beloved".'

MV659

'Hey sire, how you boast that you have deserved courtesy and loyalty! Don't speak such foolish words to me, [as to say] that you have found such baseness in your beloved, because you have falsely reproved me, [saying] I have never served love loyally: no one has ever felt the pains of love as I feel them.' 
D308, f.209r.

RS1139; MV657 (= stanza I); version of MV659 ( $\approx$ stanza II)

Versification: 7'a 3b 7'a 4b 7b 4b 7'a 7'a 7b 4b 7b 4'a

Rhymes: $a=-i e ; b=-o i$

Refrain: two-line terminal refrain vdB659 (no other refrain sources)

Other sources of this text: 6

1. W2 f.208v. Stanza I as motetus 'É bergier' MV657 written twice with single cursus of untexted tenor (O16); first version of text has empty staves; with musical notation for the second version. ${ }^{1}$

2. Mo f.195v-197r. Stanza I as motetus 'Hé bergier' MV657 with triplum 'Par un matinet' MV658 and tenor EIUS (O16); with musical notation except blank staves for last two lines of MV657. ${ }^{2}$

3. Ba f.23r. Stanza I as motetus 'Hé bergier' MV657 with triplum 'Par un matinet' MV658 and tenor EIUS (O16); with musical notation. ${ }^{3}$

4. Cl f.389r-v. Stanza I as motetus 'Le bergier' MV657 with version of stanza II as triplum 'Sire' MV659, quadruplum 'Par un matinet' MV658 and tenor EIUS (O16); with musical notation. ${ }^{4}$

5. Mo f.27v-30r. Stanza I as motetus 'Hé berchier" MV657 with version of stanza II as triplum 'Hé sire' MV659, quadruplum 'Par un matinet' MV658 and tenor EIUS (O16); with musical notation. ${ }^{5}$

6. W2 f.226v-227r (228v-229r). Version of stanza II 'Et sire' MV659 and tenor EIUS (O16); with musical notation (different melody from nos. 1-5, 7-8). ${ }^{6}$

Other sources of this melody: 2

7. StV f.291r. Incipit text 'É bergier' (in margin) only and tenor texted EIUS EIUS (O16), as textless transcribed motet; musical notation in score. ${ }^{7}$

8. W2 f.175v-176r. Latin text 'O vere lucis aurora' MV660 (melody of MV657) and tenor EIUS (O16); with musical notation. 8

\footnotetext{
${ }^{1}$ http://diglib.hab.de/mss/1099-helmst/start.htm?image=00428.

2 https://manuscrits.biu-montpellier.fr/images/196195vZ.jpg; https://manuscrits.biumontpellier.fr/images/196196rZ.jpg; https://manuscrits.biu-montpellier.fr/images/196196vZ.jpg; https://manuscrits.biu-montpellier.fr/images/196197rZ.jpg. The general site is accessed through https://manuscrits.biumontpellier.fr/vignettem.php?GENRE\%5B\%5D=MP\&ETG=OR\&ETT=OR\&ETM=OR\&BASE=manuf.

${ }^{3}$ http://digital.bib-bvb.de/webclient/DeliveryManager?custom att 2=simple viewer\&pid=2957869\#0049.

${ }^{4}$ https://gallica.bnf.fr/ark:/12148/btv1b530121530 and https://gallica.bnf.fr/ark:/12148/btv1b530121530.

5 https://manuscrits.biu-montpellier.fr/images/196027vZ.jpg; https://manuscrits.biumontpellier.fr/images/196028rZ.jpg; https://manuscrits.biu-montpellier.fr/images/196028vZ.jpg; https://manuscrits.biu-montpellier.fr/images/196029rZ.jpg; https://manuscrits.biumontpellier.fr/images/196029vZ.jpg; https://manuscrits.biu-montpellier.fr/images/196030rZ.jpg. ${ }^{6}$ http://diglib.hab.de/mss/1099-helmst/start.htm?image=00468 and http://diglib.hab.de/mss/1099helmst/start.htm?image $=00469$.

${ }^{7}$ https://gallica.bnf.fr/ark:/12148/btv1b8432457p.

8 http://diglib.hab.de/mss/1099-helmst/start.htm?image=00362 and http://diglib.hab.de/mss/1099helmst/start.htm?image $=00363$.
} 


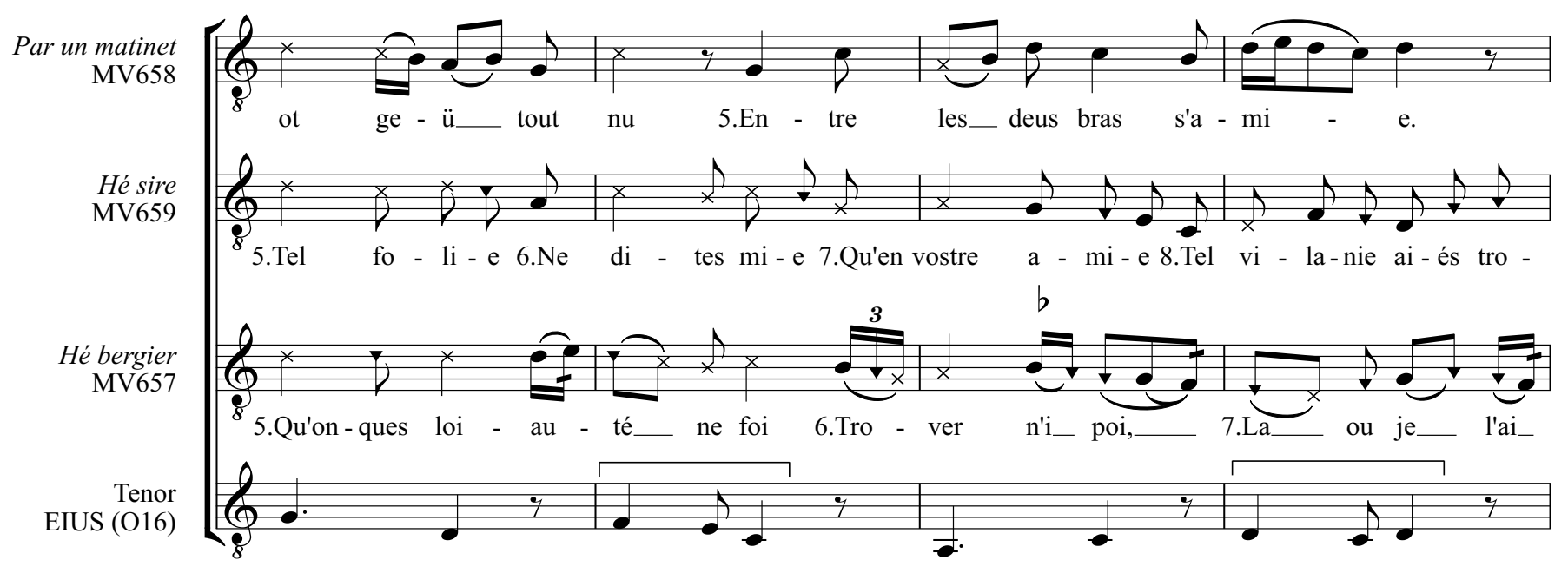




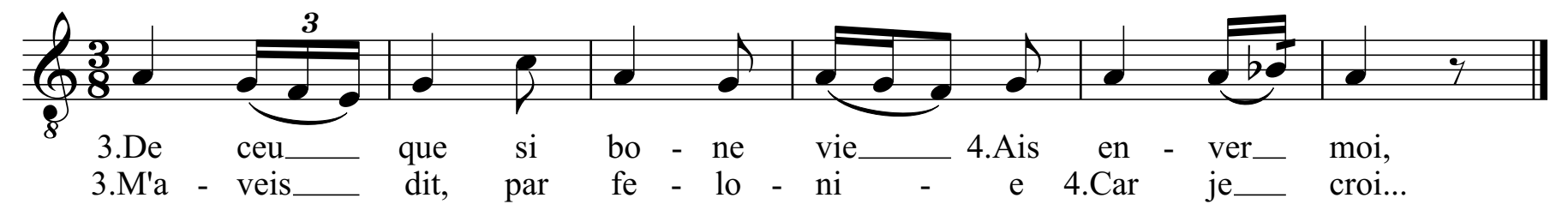

